\title{
Corporate Governance Mechanisms and Firm Performance: The Case of Ethiopian Insurance Industry
}

\author{
Asamnew Techan Demeke \\ Department of Accounting and Finance, Addis Ababa University, Addis Ababa, Ethiopia
}

Email address:

Woldemaryam21@gmail.com

\section{To cite this article:}

Asamnew Techan Demeke. Corporate Governance Mechanisms and Firm Performance: The Case of Ethiopian Insurance Industry. Journal of Investment and Management. Vol. 5, No. 2, 2015, pp. 6-16. doi: 10.11648/j.jim.20160502.11

Received: October 2, 2015; Accepted: October 20, 2015; Published: July 21, 2016

\begin{abstract}
In this study the effects of board characteristics (specifically proportion of outsiders in the board, board size, CEO-Chairman duality, and board meeting frequency), debt policy, and dividend policy are investigated in the Ethiopian context using two theories of corporate governance, which are agency theory and stewardship theory. Financial performance is measured using return on assets and return on equity. The study used panel data and Pooled OLS regression to analyze the relationship between corporate governance mechanisms and firm performance using a data set of 8 insurance companies of Ethiopia over the period 2008-2012. The results show that proportion of outside directors, board size, debt ratio, and ownership have a significant negative effect on performance of insurance companies. However, boards meeting frequency, firm size and firm age, are identified to have a significant positive impact on firm performance. Dividend policy have no effect on firm performance while the effect of CEO-Chairman Duality remains untested since it is not practiced in any one of the insurance companies.
\end{abstract}

Keywords: Board Characteristics, Corporate Governance, Financial Policies, Firm Performance, Ethiopia

\section{Introduction}

Corporate governance has become a prominent topic in Ethiopia in the last couple of decades due to reforms like the adoption of market economy, privatization of state-owned enterprises and liberalization of the financial sector to private domestic players.

The need for corporate governance arises from the separation of ownership and control in publicly held companies. Investors seek to invest their capital in profitable firms to earn returns in the future. However, many investors lack the time and expertise necessary to operate a firm and ensure that it provides a return. As a result, investors hire individuals with management expertise to run the company on a daily basis [1]. This separation of ownership from control increases the power of professional managers and left them free to pursue their own aims [2]. This results in the rise of agency problem between firm owners and managers [3].

According to [4], there are several corporate governance mechanisms to alleviate agency problems between and managers. These corporate governance mechanisms are classified as internal control mechanisms and external governance mechanisms. The internal control mechanism comprises of board of directors characteristics, compensation packages, debt policy, equity ownership by officers and directors (insider ownership), and dividend policy. The corporate governance includes the product market institutions (such as regulators responsible for competition), the market for corporate control, the labor market for managers, and the financial (capital market) institutions such as financial intermediaries, and the judiciary.

The external governance mechanisms such as the intensity of the market for corporate control and the competitiveness the labor market for managers and of the product market are common to all companies within an industry, in this case, to all insurance companies. Thus, no variation will be seen in such type of variables among companies within an industry. Variation may be seen if the focus of an inquiry becomes different industries. Coming to internal governance mechanisms, variation is expected to be seen among companies within an industry as the issues are firm specific. Thus, emphasis is given to internal governance as a mechanism to mitigate agency costs. From the internal governance mechanisms, the study is narrowed down to the effect of board characteristics and the two financial policies 
(debt policy and dividend policy) on firm performance.

Ethiopia has established basic corporate governance rules (commercial code) for share companies in the early 1960. However, despite the presence of corporate governance in the country for greater than 50 years without revision, a study conducted by [5] indicates that the rules are not adequate to safeguard minority shareholders from undue exploitation. If so, it may result in loss of confidence on the investor to make an investment. And failure to attract adequate levels of capital threatens the very existence of individual firms and can have awful consequences for the entire economy.

Although, corporate governance is a highly researched area in the developed world, there is no consensus on the role of internal corporate governance mechanisms especially board characteristics, debt [6] and dividend [7] in mitigating agency problems and associated costs. In addition, the financial sector has generally received far less attention in the corporate governance literature than seems warranted by their central role in a nation's corporate governance system [8]. Besides, only a few empirical studies (e.g [9] and [2]) have attempted to test agency theory and stewardship theory simultaneously and to the best of my knowledge there is no research work conducted on the effect of corporate governance mechanisms on firm performance particularly on the insurance industry in Ethiopia.

Therefore, this study was intended to fill these gaps by testing the two theories simultaneously in Ethiopian context. The study attempted to investigate the effect of internal corporate governance mechanisms specifically board characteristics, debt policy and dividend policy on overall corporate performance in a new setting (Ethiopia) in which financial markets are not well developed and shareholders are not well protected. In which case internal corporate governance mechanisms especially the board of directors, debt policy, dividend policy, and management compensation packages are more important as the only available control mechanism for management opportunism. Board characteristics for this study includes: proportion of outside directors, board meeting frequency, CEO-Chairman Duality and board size. The study controls for firm size, ownership and firm age. Return on asset (ROA) and Return on equity (ROE) are used as a measure of firm performance as market information about insurance companies are not available due to the absence of stock market in the country.

\section{Literature Review and Hypothesis Development}

\subsection{Literature Review}

In examining prior literature and developing the research hypothesis, this study employed two theories of corporate governance (agency theory and stewardship theory).

\subsubsection{Agency Theory}

The development of the modern corporation has resulted in companies expanding beyond the management capabilities of the owners [10]. This loss of effective control by of large corporations as firms have grown in size is essential the development of agency theory [2].

Agency theory, which is concerned with aligning the interest of owners and managers [3], has been a dominant approach in the economics and finance literatures [11]. From agency perspective, managers cannot be trusted and therefore they must be controlled to protect them from their free act to maximize their self-interest at the expense of organizational profitability [2]. According to [12], there are several mechanisms, which realign the interests of agents and principals and so reduce agency problems. These are shareholdings of insiders, institutions, and large block holders; use of outside directors, debt policy; the managerial labor market; and the market for corporate control.

The board of directors is one of several internal governance mechanisms that are intended to ensure that the interests of shareholders and managers are closely aligned, and to discipline or remove ineffective management teams [13]. Board of directors have legal duties of reviewing the corporation's major plans and actions and are also charged with selecting, compensating, evaluating, and, when appropriate, dismissing top managers [14]. The use of debt financing can also reduce agency problem by inducing monitoring by lenders [12].

In summary, with its root in industrial and organizational economics, Agency Theory assumes that human behavior is opportunistic and self-serving. Therefore, the theory recommends strong director and shareholder control. It advocates that the fundamental function of the board of directors is to control managerial behavior and ensure that managers act in the interests of shareholders.

\subsubsection{Stewardship Theory}

Stewardship theory, which dramatically opposed Agency theory, is based on the view that managers are 'steward' rather than entirely self-interested [2]. This theory assumes that managers have a wide range of motives beyond self-interest which implies that goal conflict may not be inherent in the separation of ownership from control. According to [2], stewardship theory recognizes a range of non-financial motives for managerial behavior, that agency theory failed to recognize, which includes (1) the need for achievement and recognition, (2) the intrinsic satisfaction of successful performance, and (3) respect for authority and the wdrk sethicist assumes that managers are trustworthy and work non-negligently to attain high firm profit and shareholders' returns. Thus Stewardship theory argues that the board should have a significant proportion of inside directors to ensure more effective and efficient decision making [15] and other control mechanisms are not necessary in disciplining management.

\subsection{Hypothesis Development}

\subsubsection{Proportion of Outside Directors}

A number of empirical studies have been conducted in the US on whether there is any link between outside directors 
corporate performance [16]. However, findings to date have yielded ambiguous empirical support [15]. Some studies found a positive association in support of agency theory (e.g [17], [18], [19], [20]), while others find no systematic between proportion of outsiders and measures of firm performance (e.g [21], [22], [23], [24] and [25]). There are also studies which show that outside directors are negatively related to firm performance (e.g [15] and [12]).

Preference for outsider-dominated boards is mainly grounded in agency theory [26]. From an agency theory perspective, as outside directors are assumed independent from the company's managers, they are in a better position to monitor management [27]. According to agency theory advocators outside directors are more likely to show objectivity in their deliberations and are willing to consider diverse groups in making their decisions [28]. It seems because unlike insiders, outside directors' careers are less likely to be affected by the outcomes of their decisions and thus can arrive at more objective solutions [29].

However, from stewardship theory perspective internal directors should be more helpful to the board of directors. Because their professional knowledge, abilities, and familiarity with the CEO's decision-making quality make them better at evaluating the CEO ([2] and [15]). In general, according to stewardship theorists internal directors contributes better to the performance of a firm than outside directors do as inside directors' have access to accurate, relevant and timely information, and better understanding of the business (than outside directors) as they live in the company they govern, which will help them make better decision. Based on the above discussion the study proposed:

H1: The proportion of outside directors on the board of directors of insurance companies in Ethiopia is negatively associated with firm performance.

\subsubsection{CEO-Chairman Duality}

Empirical research works relating CEO duality more specifically to firm performance find mixed evidence. A study by [20] and a meta-analysis by [30] indicate that independent leadership structure has a significant positive influence on performance. On the contrary, according to [18], the notion of separating leadership roles in a manner consistent with agency theory was not supported.

To sum up, prior studies had mixed findings on the relationship between CEO-Chairman Duality and company performance. This study proposes that:

H2: Duality is negatively related to firm performance.

\subsubsection{Board Size}

Empirical researches have not achieved consensus on the idea that larger boards will be associated with better performance. There are studies that support agency theory; for example, [20], [18], [15] and [31] find a strong positive association between board size and corporate financial performance. On the contrary [32], [24], and [33] found negative association between board size and firm performance. It is generally harder for larger groups to reach an agreement; too big board is likely to be less effective in substantive discussion of major issues [34] and would lead to free-rider problems among directors in their supervision of management. [34] recommends that board size should be limited to seven or eight members.

Generally, even if it seems good to have large board size to secure sufficient expertise on the board and to have greater exposure to the external environment that improves access to various resources, recent preference has leaned towards smaller boards. Thus, this study suggests that:

H3: There is a negative association between the size of the board and financial performance for insurance companies in Ethiopia.

\subsubsection{Board Meeting Frequency}

Several researchers have examined whether frequency of board meeting is related to better firm performance with inconsistent results. [35] found out a positive relationship between the frequency of board meetings and corporate performance while [18] and [24] documented that the number of board meetings per year is unrelated to performance. According to [35], a firm's share price decline results the increase of annual board meeting and operating performance is improved following the increment of annual board meeting.

Although the empirical evidence is not conclusive, the researcher believed that more frequent meetings should lead to better firm performance since it is the most usual occasion to discuss and exchange ideas in order to monitor managers. Thus, the study suggests:

H4: Frequency of board meeting is positively associated with firm performance.

\subsubsection{Debt Policy}

The agency literature suggests that debt may be useful in reducing agency conflicts [36] and agency costs of free cash flow ([37] and [3]) by reducing the cash flow available for spending at the discretion of managers [38]. [39], [3] and [37] also suggests that leverage which serves as a monitoring device has significant impact to mitigate agency problem between owner and principal. So, debt and equity are treated not mainly as alternative financial instruments, but rather as alternative governance structures [40].

Debt also allows public investors to notice that management do not use the free cash-flow for him/her, but it is used to pay the debt and interest periodically [41]. Therefore, a positive impact of debt ratio is expected on firm performance.

H5: There is a positive association between the debt ratio and the firm Performance.

\subsubsection{Dividend Policy}

Some studies suggest that cash payments to shareholders in the form of dividend may be helpful to reduce agency problems either by increasing the frequency of external capital raising and associated monitoring by investment bankers and investors [7], or by eliminating free cash-flow ([42], [43] and [38]). As such this paper proposes that:

H6: There is a positive association between the firm dividend payout and the firm performance. 


\section{Research Methodology}

The study is conducted on Ethiopian insurance industry. From the total population of 16insurance companies operating in the country in 2013,8 of them which have a life of six years or above are selected as a five years data are needed to conduct the study.

The data used by this study is collected from audited financial statements of the selected insurance companies and through interview conducted with each respective company's board secretary as he/she is in a better position to know information and access documents about board members size, experience, board meeting frequency and CEO duality.

Descriptive statistics is used to show the average and standard deviation of the different variables of interest in the study and Pooled OLS regression analysis is used to test the hypotheses developed above. The researcher undertakes two tests to select Pooled OLS model from fixed effects and random effects model. The result of Hausman Specification Test shows that the unobserved time-invariant firm level heterogeneities are not correlated with the independent variables employed in the study (i.e. random effect is appropriate than fixed effects model). The Breusch and Pagan Lagrangian multiplier test used to choose between random effect and simple OLS indicates that there is no panel effect or no unobserved time-invariant variations between the insurance companies that may have an impact on their performance (so Pooled OLS is appropriate). Thus, pooled ordinary least square (OLS) regression analysis is used in STATA (Windows 11.0 version) to test the hypotheses. The following regression models were used to understand the effect of corporate governance mechanisms on bank performance:

$\mathrm{Y}_{\mathrm{it}}=\alpha \mathrm{i}+\beta 1$ OUTSIDE $_{\mathrm{it}}+\beta 2$ DUALITY $_{\mathrm{it}}+\beta 3$ BDSIZE $_{\mathrm{it}}+\beta 4$ MEET $_{\mathrm{it}}+\beta 5$ DEBT $_{\mathrm{it}}$

$+\beta 6$ DIV $_{\text {it }}+\beta 7$ FSIZE $_{i t}+\beta 8$ FAGE $_{\text {it }}+\beta 9$ OWNERSHIP $_{\text {it }}+\varepsilon_{\text {it }}$ (Eq. 1$)$

Where,

- $\mathrm{Y}_{i t}$ is alternatively ROA it and ROEit for $i$ th firm at time $t$

- OUTSIDE $_{i t}$ is the proportion of outsiders in the board

- DUALIT $_{i t}$ is the CEO-Chairman Duality for $i$ th firm at time $t$,

- BDSIZE $_{i t}$ is the board size for $i$ th firm at time $t$,

- MEET $_{i t}$ meeting frequency of $i$ th firm at time $t$,

- $D E B T_{i t}$ is the debt ratio of firm $i$ in year $t$,

- $D I V_{i t}$ the dividend payout ratio of firm $\mathrm{i}$ in year $\mathrm{t}$,

- FSIZE $_{i t}$ is the firm size for $i t h$ firm at time $t$,

- $\mathrm{FAGE}_{i t}$ is the firm age for ith firm at time $t$,

- OWNERSHIP $i t$ is the ownership of $i t h$ firm at time $t$,

- $\alpha i$ is the intercept, $\beta i$ is the regression coefficient of $i$ th variable and sit is the composite error terms, and

- The subscript $I$ represents the different firms and $t$ represents the different years. The constant $\alpha i$ represents unobservable individual firm-specific effects which differ between firms and are time invariant. Unlike fixed effect model both pooled OLS and random effect model assumed that $\alpha i$ is purely random, which is uncorrelated with the errors of the regressor variables.

\subsection{Definition of the Variables and Measurement}

The researcher's choice of the variables is influenced by the previous studies on internal corporate governance control mechanisms. All the variables stated below have been used to test the hypotheses of this study. They include dependent, independent and some control variables:

\subsection{Measures of Outcome Variables: Firm Performance}

There is no single ideal measure of long-term firm performance [21]. Market based measures are viewed as somewhat more robust measure of performance given that they are not subject to direct manipulation by management which is the case for accounting measure of performance [30]. Accounting performance measures are also not without support given that stock market measures are susceptible to investors' anticipation [18]. AS the absence of secondary market in Ethiopia makes using market based measure of performance impossible, this paper used accounting measure of performance (ROA and ROE). In support of this study, other studies, for example, [18], [21] and [2] also have used accounting measures such as ROA in measuring firm performance. ROA is calculated at the firm level as the earnings before interest and taxes (EBIT) over total assets while ROE is calculated as earnings before interest and taxes (EBIT) over Shareholder's Equity.

\subsection{Measures for Variables in Hypotheses: Board Characteristics of Insurance Companies}

Proportion of Outside Board Members: Consistent to [15] and because the information collected from the sample insurance companies do not allow for any further distinction, composition of the board of directors (OUTSIDE) is measured by the proportion of outsiders in terms of the number of non-executive directors over the total number of directors.

CEO Duality: CEO-duality (DUALITY) is considered as a binary, which is equal to be one (1) if the CEO and chairperson positions are held by the same individual, otherwise zero (0).

Board Size: proxied by the number of average board of directors in each years of consideration.

Board Meeting Frequency: proxied by the number of meetings held within a year.

Debt Policy: Debt policy of firms in this study is measured by debt ratio. Debt ratio (DEBT) is the percentage of total book value of debt to total book value of assets (e.g [32] and [44]). It measures the extent to which a firm relies on creditors for funding.

Dividend Policy: Dividend policy of firms in this study is measured by dividend payout ratio (DIV). Dividends are defined as total cash dividends paid to common and preferred shareholders. Dividend payout ratio (DIV) is computed as dividends over earnings after interest and taxes but before extraordinary items. 


\subsection{Measures for Control Variables}

The model in this study controls for three possible factors that could influence firm performance. These control variables are (1) Firm size measured using the natural log of assets, (2) Firm age measured as log of the number of years for which the company has been in existence since incorporation, and (3) ownership considered as a binary, which is equal to be one (1) if the insurance company is state owned, zero (0) if it is not state owned.

Firm size: The firm size (proxy as logarithm of total assets) is established to have an effect on firm performance.

Firm Age: Given the possible influences of firm age on organizational performance, it was included as a control variable. Firm age was calculated as the natural logarithmic of number of years from the establishment of the insurance company.

State Ownership: is considered as a binary, which is equal to be one (1) if state owned and zero (0) if private.

\section{Empirical Results}

Table 1 provides descriptive statistics and correlations for the study. As per the table, the standard deviation shows that there is no that much variation on performance among the sample insurance companies.

The average board size of the 8 insurance firms used in this study is 8 (7.675) and this is in agreement with the 1960 commercial code of the country, in which the board size is required to be between 3 and 12. The average board size of this study is also consistent with optimal board size of around 8 members recommended by [34] $]^{\text {i. }}$ Furthermore, this figure is comparable to the average board size of 20 Nigerian firms, which is 9 [25].

Turning to the use of outside directors, the mean proportion of the outside directors sitting on the board (which ranges from $71.4 \%$ to $100 \%$ ) is about $84.075 \%$ of the total board size. Interestingly, one board in the sample consisted exclusively of outside directors from the year 2008 to 2012, while there are no boards that do not have any outside directors.

The proportion of outside directors in Ethiopian insurance industry is higher than required by some other countries. As the finding of [45] indicates, Indonesia requires at least 30\% of the total number of board members to be independent directors; Korea requires $25 \%$ of board members to be outside directors; Malaysia requires two directors or one-third of board members to be independent directors; and Thailand require at least two board members to be independent directors.

Outside directors are favored for its independent monitoring role [46]. However, in the case of Ethiopia the monitoring role of both outside and inside board members may be similar as both are shareholders (commercial code of Ethiopia allows only shareholders to be board member). In other words, as both outside and inside directors have an ownership they will have a strong and similar incentive to govern well. But inside directors may be superior in enhancing firm performance as they have accurate and timely day-to-day information and more knowledge of the business that is needed to make sound firm decision. Thus, the $84.075 \%$ proportion of outside directors may not be good.

Table 1 also indicates that $100 \%$ of the sample firms have separate persons occupying the posts of the chief executive and the board chairman, demonstrating that CEO duality is not totally practiced in Ethiopian insurance industry. This suggests that all the firms are voluntarily complying with the suggestions for best practice as supported by various international bodies like Sarbanes-Oxley (SOX) and it is in support of agency theory. This result is consistent with a finding by [45] which indicates that the positions of CEO and board chairpersons are separate for $88 \%$ of the Malaysian firms, $82 \%$ of the Thai firms and $100 \%$ of the Indonesian firms. However, the positions of CEO and board chairperson are combined in more than $75 \%$ of large companies in the United States [30]; 93\% in Korean firms [45] and 65 percent in the United Arab Emirates banking industry [31].

Allowing board chairman to also serve as the CEO (or vice versa) gives him both playing roles of decision-maker and supervisor simultaneously and so the board could lose its independence and monitoring power. Thus, directive No. SBB/39/2006 issued by National Bank of Ethiopia, which prohibits chair-person of board of directors from being chief executive officer seems good and appropriate.

Table 1. Mean, Standard Deviation and Correlation: Financial and Operational Data of Sample Insurance Companies.

\begin{tabular}{|c|c|c|c|c|c|c|c|c|c|c|c|c|}
\hline & Mean & SD & (1) & (2) & (3) & (4) & (5) & (6) & (7) & (8) & (9) & (10) \\
\hline \multicolumn{13}{|l|}{ Dependant } \\
\hline Variables & & & & & & & & & & & & \\
\hline 01. ROA & .066 & .0303 & 1.0000 & & & & & & & & & \\
\hline 02. ROE & .186 & .0932 & $0.796 * * *$ & 1.0000 & & & & & & & & \\
\hline Predictors & & & & & & & & & & & & \\
\hline 03. Outside & .841 & .075 & 0.0170 & $-0.2803^{*}$ & 1.0000 & & & & & & & \\
\hline 04. Bodsize & 7.68 & 1.47 & $-0.2981 *$ & -0.1363 & $0.284 *$ & 1.0000 & & & & & & \\
\hline 05. Meet & 12.24 & 6.212 & 0.0151 & 0.2609 & $0.44^{* * *}$ & $0.424 * * *$ & 1.0000 & & & & & \\
\hline 06. Debt & .59 & .161 & -0.2706 & 0.1863 & $-0.62 * * *$ & 0.0532 & 0.0706 & 1.0000 & & & & \\
\hline 07. Div & .453 & .359 & -0.0341 & -0.0351 & 0.1316 & -0.1594 & 0.1067 & 0.2191 & 1.0000 & & & \\
\hline Controls & & & & & & & & & & & & \\
\hline 08. Fsize & 8.196 & .434 & 0.1658 & $0.4332^{* * *}$ & -0.1436 & $0.2926^{*}$ & $0.2738^{*}$ & $0.458^{* * *}$ & 0.065 & 1.00 & & \\
\hline 09. Fage & 1.11 & .216 & 0.1128 & $0.4979 * * *$ & $-0.389 * *$ & 0.1123 & $0.2698^{*}$ & $0.7012 * * *$ & 0.07 & $0.804 * * *$ & 1.0000 & \\
\hline 10. Ownership & .125 & .335 & 0.1424 & $0.4601 * * *$ & 0.0781 & 0.1363 & $0.725 * * *$ & $0.357 * *$ & 0.1714 & $0.745 * * *$ & $0.745 * * *$ & 1.00 \\
\hline
\end{tabular}

$\mathrm{N}=40 ; * \mathrm{P}<0.1 ; * \mathrm{p}<0.05 ; * * * \mathrm{p}<0.01$ 
The data set is for 8 insurance companies over the period 2008-2012. Duality does not have value as CEO-chairman duality is not practiced in the country and is not included in the correlation table.

Average frequency of board meetings positioned to 12.24 times per the considered financial year. In addition to the standard deviation (6.21), the minimum (4) and maximum (24) values of meeting frequency reveals that there is a broad range of variation in the sample insurance companies.

The average Total Debt to Total Assets (DEBT) is 59\% (58.99\%) ranging from $20.2 \%$ to $75 \%$. This means at minimum $20.2 \%$ of an insurance company is financed by debt while on average $59 \%$ of insurance company's assets is financed by using debt. This indicates that only less than half of the insurance company's asset is financed by equity.

The range $(0 \%$ to $151.7 \%)$ and standard deviation (36\%) of dividend payout ratio (compared to the mean $45.2 \%$ ) shows there is high variation among sample insurance companies and across time in paying dividends. The minimum dividend payout ratio $(0 \%)$ indicates that there is insurance company which did not pay dividend or time period in which dividend is not payed. Low or zero dividends may in turn show the presence of better investment opportunities. Because firms with growth opportunities may prefer retaining and using their cheaper source of financing (internal source of finance) to paying dividends and go to market to generate funds through issuing equity securities and/or debt securities. The maximum dividend payout ratio $(151.7 \%)$ indicates that there is insurance company, which pays dividend more than what it earns. Higher dividend payout ratio may signal good performance. It may also show the absence of growth opportunities. That is why according to Easterbrook [7], someone who observes an increase in the dividend has no very good way to tell whether this signals good or bad times.

\subsection{Estimation Methods and Test of OLS Assumptions}

Before conducting the main analyses, the assumptions for multiple regression analysis are checked. Among the several important assumptions of classical linear regression model this study tests heteroskedasticity, normality of residuals, functional form test, and multi-collinearity. Additionally, a robust regression (using the command 'rreg') is performed in order to verify whether OLS findings are affected by outlier observations but no notable difference is observed. Therefore, OLS estimation is employed without the need of robust regression. Autocorrelation is not tested as serial correlation is not a major problem for micro panels (few years and large number of cases) [47].

Breusch Pagan / Cook-Weisberg test used to detect the existence of heteroskedasticity indicates that there is no problem of heteroskedasticity in both models (see table 2 below).

Table 2. Breusch-Pagan / Cook-Weisberg test for heteroskedasticity.

\begin{tabular}{lll}
\hline Ho: Constant variance & & \\
\hline Variables: & chi2 (1) & Prob>chi2 \\
\hline Fitted values of ROA & 0.48 & 0.4880 \\
Fitted values of ROE & 2.11 & 0.1464 \\
\hline
\end{tabular}

Shapiro-Wilk W test used to check the normality of the residuals from the OLS regression shows that the residuals are normally distributed (p 0.49498). In addition, graphical test for normality (Kernel Density Estimate) is employed and normality is identified as not a problem (see table 3 below).

Table 3. Shapiro-Wilk W test for normal data.

\begin{tabular}{llllll}
\hline Variable & Obs & W & V & z & Prob $>\mathbf{z}$ \\
\hline $\mathrm{r}$ & 40 & 0.97455 & 1.006 & 0.013 & 0.49498 \\
\hline
\end{tabular}

Multicollinearity, checked by using variance inflation factors (VIFs), is not a serious problem for this analysis as the VIF values shown below in Table 4 are below the recommended cutoff point.

Table 4. VIF Test Results.

\begin{tabular}{llllllllll}
\hline Variable & Ownership & Fage & Meet & Fsize & Debt & Outside & Bodsize & Div & Mean VIF \\
\hline VIF & 14.99 & 8.14 & 7.61 & 5.22 & 4.17 & 3.56 & 1.74 & 1.38 & 5.85 \\
$1 /$ VIF & 0.066705 & 0.122818 & 0.131416 & 0.191568 & 0.239750 & 0.280673 & 0.575700 & 0.724896 & \\
\hline
\end{tabular}

To test the functional form of the conditional mean, two methods are applied by this study. These are the RESET test resulted from the estat ovtest post estimation command and the link test. Results for the first test shows that the null hypothesis that there is no omitted variable is accepted in both Models (see table 5 below).

Table 5. Ramsey RESET test.

\begin{tabular}{lll}
\hline Ho: model has no omitted variables & & \\
\hline Ramsey test & F value & Prob $>$ F \\
\hline using powers of the fitted values of roa & 2.58 & 0.0738 \\
using powers of the fitted values of roe & 2.30 & 0.0986 \\
\hline
\end{tabular}

\subsection{Regression Results}

As can be seen from table 6 and 7 below the regressors are jointly statistically significant, because the overall $\mathrm{F}$ static of 7.44 for Model one and 9.57 for Model two have $\mathrm{P}$ value of 0.000. In other words, independent variables are jointly capable of explaining the dependent variable. At the same time, much of the variation is explained by the Models with R-squared of $=0.6575$ and $=0.7118$ in Model 1 and Model 2 respectively. 
Table 6. Pooled Ordinary least squares estimation results, ROA (Model One).

\begin{tabular}{lllllll}
\hline Roa & Coef. & Std. Err. & T-test & P $>\mathbf{t}$ & $\mathbf{9 5 \%}$ Conf. & Interval \\
\hline Outside & -.158265 & .0794809 & -1.99 & 0.055 & -.3203674 & .0038374 \\
Bodsize & -.0223778 & .0042888 & -5.22 & 0.000 & -.0311248 & -.0136308 \\
Meet & .0091197 & .001889 & 4.83 & 0.000 & .0052671 & .0129723 \\
Debt & -.219803 & .0407856 & -5.39 & 0.000 & -.3029857 & -.1366203 \\
Div & .0140883 & .0107532 & 1.31 & 0.200 & -.007843 & .0360196 \\
Fsize & .0997721 & .022077 & 4.52 & 0.000 & .0547458 & .1447984 \\
Fage & .1607819 & .0426686 & 3.77 & 0.001 & .0737588 & .247805 \\
Ownership & -.2319026 & .0496857 & -4.67 & 0.000 & -.3332372 & -.130568 \\
cons & -.5850834 & .1815395 & -3.22 & 0.003 & -.9553355 & -.2148312 \\
\hline
\end{tabular}

Number of obs $=40, F(8,31)=7.44$, Prob $>F=0.0000, R$-squared $=0.6575$,

Adj R-squared $=0.5691$

Table 7. Pooled Ordinary least squares estimation results, ROE (Model Two).

\begin{tabular}{|c|c|c|c|c|c|c|}
\hline Roe & Coef. & Std. Err. & $\mathbf{T}$ & $P>t$ & 95\% Conf. & Interval \\
\hline Outside & -.8778292 & .2240592 & -3.92 & 0.000 & -1.334801 & -.4208574 \\
\hline Bodsize & -.0567378 & .0120902 & -4.69 & 0.000 & -.0813959 & -.0320797 \\
\hline Meet & .0297848 & .0053251 & 5.59 & 0.000 & .0189241 & .0406455 \\
\hline Debt & -.5127483 & .1149758 & -4.46 & 0.000 & -.7472431 & -.2782536 \\
\hline Div & .0320909 & .0303136 & 1.06 & 0.298 & -.0297341 & .0939159 \\
\hline Fsize & .2743177 & .0622357 & 4.41 & 0.000 & .1473872 & .4012482 \\
\hline Ownership & -.619903 & .1400654 & -4.43 & 0.000 & -.9055683 & -.3342376 \\
\hline cons & -1.383248 & .5117654 & -2.70 & 0.011 & -2.427001 & -.3394958 \\
\hline
\end{tabular}

Number of obs $=40, F(8,31)=9.57$, Prob $>F=0.0000$, R-squared $=0.7118$

Adj R-squared $=0.6375$

\subsection{Proportion of Outside Board of Directors}

The first hypothesis of interest is proportion of outside directors ${ }^{1}$. To analyze whether the presence of outside directors on the board has any influence on the performance of the firm, regressions with performance variables of ROA and ROE as dependent variables and proportion of outside directors (outside directors as a percentage of the total board size) as explanatory variable were estimated.

As shown in Tables 6 and 7 above the percentage of outside directors (OUTSIDE) is negatively and marginally significant in most instances when both ROA and ROE are used as the performance variable $(b=-.158265, t=-1.99$, $p 0.055<0.1$ and $\mathrm{b}=-.8778292, \mathrm{t}=-3.92, \mathrm{p} 0.000<0.05$ respectively). The implication of this is that for the sample insurance companies, there is a negative relationship between the firms' financial performances and the outside directors sitting on the board.

Unlike previous researches, ${ }^{2}$ the effect of proportion of outsiders on performance of firms in this study is not conditional on the performance measures employed (i.e it has

1 The term board composition is used by various studies to represent the proportion of outside board of directors. See Jackling and Johl (2009).

2 According to Jackling and Johl percentage of outside directors (OUTSIDE) has positive and marginally significant effect when Tobin's $Q$ (TQ) is used as the performance variable $(\mathrm{b}=3.44, \mathrm{z}=1.52, \mathrm{p}<.10)$. But the significance disappears when ROA is used as the performance dependent variable. Peng (2004) also founds that outside directors make a difference when sales growth is used as a measure of performance and have no when ROE is used. the same effect on both performance measures). So stewardship theory's argument that internal directors are more helpful than outsiders as their professional knowledge, abilities, and familiarity with the CEO's decision-making quality make them better at evaluating the CEO [2] is accepted. However, agency theory which argues that outside director dominated boards are better positioned to protect shareholders interest and hence enhance firm's performance is not supported under both measures of performance.

A proponent of stewardship theory argues that inside directors are better to foster performance than outside directors [2]. The result of this study supports this argument. This may be because inside directors have access to accurate, relevant and timely information, and better understanding of the business (than outside directors), which is key to make better decision.

The result, outside directors are negatively related to firm performance, is consistent with some previous empirical studies (e.g [15] and [12]), implying that super-majority outside directors cannot add potential economic value to insurance companies instead, have a destructive effect. This leads to pay attention to what is suggested by [21]. According to [21], supermajority-outside boards are less profitable than other firms and they suggests that having a moderate number of inside directors (three to five on an average-sized eleven member board) is important to enhance firm performance.

Generally, the stewardship theory based hypothesis that the proportion of outside directors is negatively associated with 
financial performance of insurance companies in Ethiopia is accepted. However, the conventional wisdom that an independent board is preferable to a board made up mainly of company insiders is not supported.

\subsection{CEO-Chairman Duality}

The second hypothesis is to test whether various aspects of board leadership structure affect firm performance. However, as there is no CEO-Chairman Duality in all sample companies, the OLS regression doesn't have a value for the variable DUALITY. As a result, the researcher is not in a position to relate CEO-Chairman Duality with firm performance. But separation of CEO and board chairman position in all sampled firms seems more than in agreement with agency theory, which argues that the same person should not hold the CEO and chairman roles at the same time, as this will reduce the effectiveness of board monitoring. This also suggests that about $100 \%$ of the firms are voluntarily complying with the suggestions for best practice as supported by various international bodies (eg. Sarbanes-Oxley (SOX)).

\subsection{Board Size}

The variable tested in hypothesis three is board size (BODSIZE). According to table 6 and 7, the pooled OLS estimation result shows that board size is significantly and negatively related with financial performance of companies under both ROA and ROE measures (with similar P value: $0,000<0,05)$. This means smaller boards are more efficient than the larger ones and so lead to better financial performance. The coefficient of the variable is -.0223778 under ROA and -.0567378 under ROE, which means $1 \%$ increase in total board size decreases ROA and ROE approximately by $2.24 \%$ and $5.674 \%$ respectively.

Thus, agency theory which argues that a larger board is more likely to be watchful for agency problems as large number of boards will be reviewing manager's actions (as it provide more monitoring resources) and so increases firm performance is not supported. It may be because as the study of [48] shows, larger board size makes coordination, communication and decision-making more troublesome and it may cause free-riding issues among the many board members.

The findings support prior studies such as [33], [24], [48], and [11]. These authors found inverse association between board size and firm performance. Some of them also suggest about the optimal size of the board. For example [34], suggests that board size around eight is optimal and according to [16] the board size limit of six is suggested as the ideal.

Although, as presented on the descriptive statistics the average board size is consistent with the optimal board size suggested by [34], the regression result show that board size is significantly negatively related with firm performance, implying that the optimal board size suggested by Jensen is not optimal for insurance companies in Ethiopia.

However, the results contrast with the earlier work of [25] and [20] as their finding indicates that larger boards are significantly positively associated with firm performance. It also did not support [49], who found out that board size is unrelated with financial performance of Turkish firms and [35], who concluded that increases in board size are found to be positively associated with annual stock returns.

Overall, the results provide strong support for the hypothesis $(H 3)$ that board size is negatively related with firm performance. It is consistent with the theory that when boards get to be too big, agency problem increases and the board becomes more symbolic and less a part of the management process [11] and it becomes easier for the CEO to control.

\subsection{Board Meeting Frequency}

The last but not the least variable within board characteristics tested in hypothesis four $(\mathrm{H} 4)$ is frequency of board meeting. In both models presented in Table 6 and 7 board meeting frequency is significantly related to firm performance measured by ROA (p-value 0.000) and ROE ( $p$-value 0.000 ). For this reason, boards that meet frequently are more likely to perform their duties non-negligently and in accordance with shareholders interest. That is why the amount of time and effort directors devote to board meetings is taken as an indicator of board effectiveness [45]. The result in this study is in favor of the work of [35] as his finding shows that frequent board meetings are followed by enhanced firm performance.

In Ethiopia, since shareholders are only allowed to be a board member, high board meeting frequency may indicate significant involvement of shareholders on the management decision. High owner involvement on management decision in turn can promote firm performance as it may be difficult for the management to pass a decision that benefits him at the expense of the owners closely watching him. So, it is not amazing to get a result that board meeting frequency has positive and significant effect on firm's financial performance which is consistent to the hypothesis (H4).

\subsection{Debt Policy}

The study shows that firms that have huge proportions of debt in their asset portfolio perform worse than otherwise. The significant negative association of debt ratio with both ROA and $\operatorname{ROE}$ ( $\mathrm{p}$ value $=0.000$ and 0.000 respectively) implies that firms with higher levels of debt as a proportion of total asset may have a worse financial performance. It may also express that highly profitable firms have less need of external funds. This significant negative relationship between debt ratio and firm performance does not support the agency theory and [12]; [36]; [3] and [37] argument that debt disciplines management (by inducing monitoring by lenders) and hence improves performance. But the inverse relationship between debt ratio and firm performance is similar with the finding of [50] conducted on UAE firms using cross-sectional analysis.

The negative result may be due to higher interest payments of firms with high debt ratio to meet their obligation can cause serious cash problems and reduce significantly the firm's earnings which would have a negative impact on their performance (ROA). 
In sum, based on the empirical result of this study the hypothesis that, there is a negative association between the debt ratio and the firm Performance is accepted.

\subsection{Dividend Policy}

Both Model one and Model two (table 6 and 7) shows that dividend payout ratio has no effect on the performance of firms ( $p$ value of 0.200 and 0.298 respectively). The agency theoretical argument that dividend plays a disciplining role is not supported by this study. This may be because of the absence of stock market in the country.

As pointed out by [7], higher dividend payout controls agency problem by increasing the likelihood that the firm will have to sell common stock in primary capital markets. This may in turn leads to an investigation of management by investment banks, securities exchanges and capital suppliers. But in Ethiopia, common stocks are not sold at the price the market gives to it (the price determined by investment banks, securities exchanges and capital suppliers) due to the absence of strong market. As a result, dividend cut may not be penalized by the market through stock price reduction in the country.

[43] found out that firms with stronger corporate governance have higher dividend payout. But the Pearson correlation matrix in this study indicates that dividend payout is not correlated with other control mechanisms (see table 1).

\subsection{Other Variables}

Firm size is significantly and positively related to performance ( $p$ value: 0.000 in both Model one and Model two), suggesting that larger firms are likely to exploit economies of scale, employ more skilled managers and get more market power. It may also be because corporate governance appears to be better in larger firms [45]. The coefficient for firm size proxied by log (total asset) is 0.0998 in case of ROA and 0.2743 in case of ROE. This means that $1 \%$ increase in $\log$ (total assets) will result $10 \%$ increase in ROA and $27.43 \%$ increase in ROE.

The result also shows that ownership ( 1 if owned by state and 0 otherwise) is significant at explaining ROA and ROE (P value: 0.000 in both cases). This significant negative result is in agreement with the agency theory argument that managers of state owned firms are inefficient due to the lack of market monitoring [37]. It may also be because managers of state owned companies may not face as much pressure from the environment as managers of private companies. In addition, the monitoring role of boards of Ethiopian state owned insurance companies may not be as good as that of private insurance companies. Because unlike the case for private companies, board members for state owned companies are not owners (shareholders).

Firm age also has positive and significant effect (at 5\%) on firm performance under both ROA and ROE which is contradicted with the work of $[51]^{3}$. The result is also not consistent [52], who found out that firm size and firm age are inversely related to firm performance, suggesting that larger and older firms may have more agency conflicts.

\section{Conclusion}

The study examines whether internal corporate governance mechanisms affect the financial performance of the firms.

Although inconclusive, in the literature review the findings of this study shows that proportion of outside directors have a significant negative effect on firm performance (ROA and ROE).

The other board characteristics board size is also identified to have a significant negative correlation with firm performance. The result for proportion of outside directors and board size is in the support of stewardship theory, which argues that managers are stewards and being monitored by outsiders and large group is unnecessary. However, more frequent board meeting leads to higher firm performance. Implying that, frequent meetings let for better communication between management and directors, which intern can enhance performance.

In relation to other internal corporate governance mechanisms the OLS result indicates that the level of debt is inversely related to firm performance, while dividend payout ratio have no effect on performance of firms. The argument that debt and dividend can be used as a monitoring device through reduction of free cash flow and increasing the frequency of external capital raising and associated monitoring by investment bankers and investor cannot work in Ethiopian insurance industry.

Finally, from among the control variables firm size, firm age and ownership have significant effect on performance. The effect of firm size and age are positive, whereas, ownership is identified to affect firm performance negatively.

The study provides no support for aspects of agency theory as proportion of outside directors on boards, board size, and debt policy have negative effect on performance while dividend policy were unrelated with firm performance. But the notion of separating leadership roles in a manner consistent with agency theory is followed $100 \%$ in the country but difficult to test it empirically since all the sample firms have independent leadership structure. Generally, consistent with Tian and Lau (2001) the stewardship hypotheses received stronger empirical support.

\section{Limitations and Suggestion for Further Studies}

Like any other research, there are some inherent limitations with the findings of this study. First, there are other potentially effective internal corporate governance mechanisms that this study fails to consider such as managerial compensation, shareholding of insiders, institutions, and large block holders. 
Secondly, there may be potential endogeneity problem between some of internal corporate governance mechanisms and firm performance. For example if we take proportion of outside directors, on the one hand, it can be argued that a higher proportion of outside directors would increase firm performance and, on the other hand, it is also possible that firms change board composition in response to firm performance. Therefore, further researchers should incorporate and consider such important points in examining the effect of corporate governance mechanisms on firm performance.

\section{References}

[1] The Institute of Chartered Accountants of Pakistan (2006). Instituting Corporate Governance in Developing, Emerging and Transitional Economies.

[2] Muth M. M. and Donaldson L. (1998). Stewardship Theory and Board Structure: a Contingency Approach. Scholarly Research and Theory Papers, 6 (1), 5-28.

[3] Jensen, M. C. and Meckling, W. (1976). Theory of the firm: managerial behavior, agency costs, and ownership structure, Journal of Financial Economics, 4, 305-60.

[4] Belkhir M. (2009). Board of directors' size and performance in the banking industry. International Journal of Managerial Finance 5, 201-221.

[5] Fekadu, Petros G. (2010). Control in Ethiopian Share Companies: Legal and Policy Implications. Mizan Law Review $4(1), 1-30$.

[6] Florackis C and Okan A (2004). Agency cost and Corporate Governance Mechanism: Evidence for UK Firms, Working Paper, University of York, UK.

[7] Easterbrook F. (1984). Two agency cost explanation of dividends. American Economic Review 74, 650-659.

[8] Jr., Gerard C. and Levine R. (2002). Corporate Governance in Finance: Concepts and International Observations. Conference paper.

[9] TIAN, J. J. and LAU, CHUNG-MING (2001). Board Composition, Leadership Structure and Performance in Chinese Shareholding Companies. Asia Pacific Journal of Management, $18,245-263$.

[10] Siladi B. (2006). Corporate Governance: An Evaluation. Un-published.

[11] Hermalin, B. E., and Weisbach, M. S. (2000). Board of Directors as an Endogenously Determined Institution: A Survey of the Literature. University of California at Berkeley and University of Illinois Working Paper.

[12] Agrawal and C. Knoeber (1996). Firm Performance and Mechanisms to control Agency Problems between Managers and Shareholders. Journal of Financial and Quantitative Analysis 31 (3), 377-397.

[13] Kang H., Cheng M. and Gray S. J. (2007). Corporate Governance and Board Composition: diversity and independence of Australian boards. Corporate Governance, 15 (2), 194-207.
[14] Shivadasani, A., and David Yermark (1999). CEO involvement in the selection of new board members: An Empirical Analysis. Journal of Finance 54, 1829-1853.

[15] Kiel G. C. and Nicholson G. J. (2003). Boards that Work: A New Guide for Directors, McGraw Hill, Sydney.

[16] Garg, A. K. (2007). Influence of Board Size and Independence on Firm Performance: A Study of Indian Companies. Research, 32 (3), 39-60.

[17] Perry, T. and Shivdasani, A. (2005). Do Boards Affect Performance? Evidence from Corporate Restructuring. The Journal of Business, 78 (4), 1403-1432.

[18] Jackling B. and Johl S. (2009). Board Structure and Firm Performance: Evidence from India's Top Companies. Corporate Governance: An International Review, 17 (4): 492-509.

[19] Ameer R., Ramli F. and Zakaria H. (2010). A new perspective on board composition and firm performance in an emerging market., 10, 647-661.

[20] Uadiale, O., M. (2010). The Impact of Board Structure on Corporate Financial Performance in Nigeria. International Journal of Business and Management, 5 (10), 155-166.

[21] Bhagat, S., and B. Black 2000. "Board Independence and Long-Term Firm Performance." Unpublished paper, University of Colorado.

[22] Hermalin, B. E., and Weisbach, M. S. (2003). Board of Directors as an Endogenously Determined Institution: A Survey of the Economic Literature. Economic Policy Review, 9 (1), $7-26$.

[23] Peng, M. W. (2004). Outside Directors and Firm Performance during Institutional Transitions. Strategic Management Journal, $25,453-471$.

[24] Andres Pablo de, Azofra V. and Lopez F. (2005). Corporate Boards in OECD Countries: size, composition, functioning and effectiveness. Corporate Governance, 13 (2), 197-210.

[25] Kajola, Sunday O, (2008). Corporate Governance and Firm Performance: The Case of Nigerian Listed Firm. European Journal of Economics, Finance and Administrative Sciences, ISSN 1450-2887 Issue 14.

[26] Dalton, D. R., Daily, C. M., Ellstrand, A. E., and Johnson, L. J. (1998). Meta - Analytic Review of Board Composition, Leadership Structure and Financial Performance. Strategic Management Journal, 19 (3), 269-290.

[27] Fama, Eugene F., and Jensen, Michael C. (1983). Separation of Ownership and Control. Journal of Law and Economics, 26, 301-25.

[28] Nam, SW. \& Nam, IL. Chong (2004). Corporate governance in Asia: Recent Evidence from Indonesia, Republic of Korea, Malaysia, and Thailand. Unpublished manuscript, Asian Development Bank Institute, Tokyo.

[29] Valenti M. A., Luce R., Mayfield C., (2011). The effects of firm performance on corporate governance. Management Research Review, 34 (3), 266 - 283.

[30] Rhoades, D. L., Rechner, P., L. and sundaramurthy Chamu (2001). A Meta-analysis of Board Leadership Structure and Financial Performance: are "two heads better than one"? Empirical Research-based and Theory-building Papers, 9, 311-319. 
[31] Mohamed Belkhir, (2009) "Board of directors' size and performance in the banking industry", International Journal of Managerial Finance, 5 (2), 201 - 221.

[32] Rashid, A., De Zoysa, A., Lodh, S. and Rudkin, K. (2010). Board Composition and Firm Performance: Evidence from Bangladesh. Australasian Accounting Business and Finance Journal, 4 (1), 76-95.

[33] Yermack, David (1996). Higher market valuation of companies with a small board of directors. Journal of Financial Economics $40,185-212$.

[34] Jensen, M. C. (1993). The modern industrial revolution, exit, and the failure of internal control systems. The Journal of Finance, 48 (3), 831-80.

[35] Vafeas N. (2003). Length of Board Tenure and Outside Director Independence. Journal of Business Finance \& Accounting, 30 (7) \& (8), 1043-1063.

[36] Bathala C. T., Moon K. P., and Rao R. P. (1994). Managerial Ownership, Debt Policy, and the Impact of Institutional Holdings: An Agency Perspective. Financial Management, 23 (3), 38-50.

[37] Fatma, BEN M. and Chichti, Jameleddine (2011). Interactions between Free Cash Flow, Debt Policy and Structure of Governance: Three Stage Least Square Simultaneous Model Approach. Journal of Management Research, 3 (2).

[38] Jensen, M. (1986). Agency cost of free cash flow, corporate finance and takeovers. American Economic Review Papers and Proceedings, 76, 323-329.

[39] Litov L. P. (2005). Corporate Governance and Financing Policy: New Evidence.

[40] Williamson, O., E. (1988). Corporate Finance and Corporate Governance. The Journal of Finance, 43 (3), 567-591.

[41] Alwi s. (2009). Dividend and Debt Policy as Corporate Governance Mechanism: Indonesian Evidence. Jurnal Pengurusan, 29, 111-127.

[42] Utami, S., R. and Inanga Eno L. (2011). Agency Costs of Free Cash Flow, Dividend Policy, and Leverage of Firms in
Indonesia. European Journal of Economics, Finance and Administrative Science, 7_24.

[43] Adjaoud F. and Ben-Amar W. (2010). Corporate Governance and Dividend Policy: Shareholders' Protection or Expropriation? Journal of Business Finance \& Accounting, 37 (5) \& (6), 648667.

[44] Khatab H., Masood M., Zaman K., Saleem S. and Saeed B. (2011). Corporate Governance and Firm Performance: A Case study of Karachi Stock Market. International Journal of Trade, Economics and Finance, 2 (1), 39-43.

[45] Nam, SW. \& Nam, IL. Chong (2004). Corporate governance in Asia: Recent Evidence from Indonesia, Republic of Korea, Malaysia, and Thailand. Unpublished manuscript, Asian Development Bank Institute, Tokyo.

[46] Fama, E., and M. Jensen (1983). Separation of Ownership and Control. Journal of Law and Economics 26, 301-25.

[47] Baltagi, B. H. (2005): Econometric Analysis of Panel Data, Third edition. Chichester: Wiley.

[48] Ramdani D. and Witteloostuijn A. van (2010). The Impact of Board Independence and CEO Duality on Firm Performance: A Quantile Regression Analysis for Indonesia, Malaysia, South Korea and Thailand. British Journal of Management, 21, 607626.

[49] Topak, Mehmet S. (2011). The Effect of Board Size on Firm Performance: Evidence from Turkey. Middle Eastern Finance and Economics, 14, 119-127.

[50] Aljifri, K. and Moustafa M. (2007). The Impact of Corporate Governance Mechanisms on the Performance of UAE Firms: An Empirical Analysis. Journal of Economic \& Administrative Sciences, 23 (2), 71-93.

[51] Bennedsen M., Kongsted H. C., and Nielsen K. M. (2008). The causal effect of board size in the performance of small and medium-sized firms. Journal of Banking \& Finance 32, 1098 1109.

[52] Peng M. (2004). Outside Directors and Firm Performance during Institutional Transitions. Strategic Management Journal, $25,453-471$. 